\title{
GMR
}

\section{Intestinal alkaline phosphatase and sodium butyrate may be beneficial in attenuating LPS-induced intestinal inflammation}

\author{
A.D.B. Melo ${ }^{1,3}$, H. Silveira ${ }^{2}$, C. Bortoluzzi ${ }^{3}$, L.J. Lara ${ }^{2}$, C.A.P. Garbossa ${ }^{4}$, \\ G. Preis ${ }^{5}$, L.B. Costa $^{1}$ and M.H. Rostagno ${ }^{3}$ \\ ${ }^{1}$ Pontifícia Universidade Católica do Paraná, Curitiba, PR, Brasil \\ ${ }^{2}$ Universidade Federal de Lavras, Lavras, MG, Brasil \\ ${ }^{3}$ Purdue University, West Lafayette, IN, USA \\ ${ }^{4}$ Universidade Federal Rural da Amazônia, Paragominas, PA, Brasil \\ ${ }^{5}$ Universidade do Estado de Santa Catarina, Lages, SC, Brasil \\ Corresponding author: A.D.B. Melo \\ E-mail: diegobmelo@hotmail.com
}

Genet. Mol. Res. 15 (4): gmr15048875

Received June 10, 2016

Accepted July 20, 2016

Published October 17, 2016

DOI http://dx.doi.org/10.4238/gmr15048875

Copyright (C) 2016 The Authors. This is an open-access article distributed under the terms of the Creative Commons Attribution ShareAlike (CC BY-SA) 4.0 License.

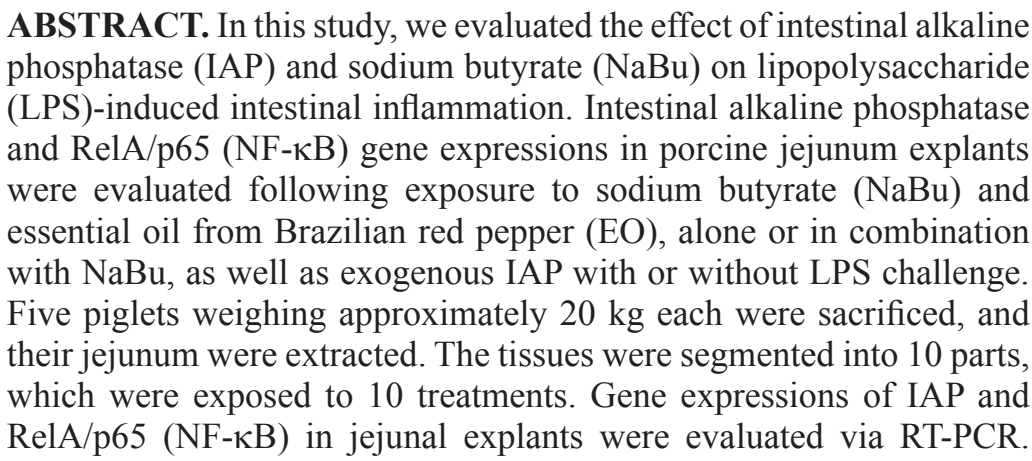

Genetics and Molecular Research 15 (4): gmr15048875 
We found that $\mathrm{EO}, \mathrm{NaBu}$, and exogenous IAP were able to up-regulate endogenous IAP and enhance RelA/p65 (NF- $\kappa \mathrm{B})$ gene expression. However, only $\mathrm{NaBu}$ and exogenous IAP down-regulated LPS-

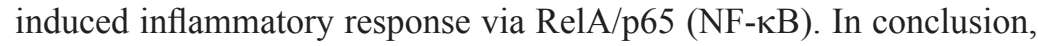
we demonstrated that exogenous IAP and $\mathrm{NaBu}$ may be beneficial in attenuating LPS-induced intestinal inflammation.

Key words: Brazilian red pepper essential oil; Ex vivo; Swine; Intestinal alkaline phosphatase; Intestinal explants; Sodium butyrate;

\section{INTRODUCTION}

Bacterial lipopolysaccharides (LPS), the major components of the outer membranes of Gram-negative bacteria, are potent inflammatory inducers (Islam and Pestka, 2006; Bortoluzzi et al., 2016), and may be associated with inflammatory bowel disease (IBD) and sepsis. The resident gut microbiome is one of the most abundant sources of LPS in humans and animals. Dysbiosis of gut microbiota has been linked to intestinal inflammation (Malo et al., 2014). There are much difficulties associated with studying gene expression in human tissues, especially in the intestinal tract. Owing to the similarities in intestinal physiology between pigs and humans, studies that examine the relationship between immune inducers and nutritional influences are preferably carried out in pig models (Roura et al., 2016).

The viability of ex vivo techniques has been recently investigated to evaluate the modulatory effects of natural agents on immune responses in intestinal explants (Bahar et al., 2012; Leonard et al., 2012). Furthermore, ex vivo techniques applied in these studies may offer a quick, less expensive, specific, and reliable experimental model to determine the effects of immune inducers or feed contaminants on intestinal mucosa (Basso et al., 2013; Bortoluzzi et al., 2016).

Herbal extracts and organic acids are natural compounds that have been associated with enhanced gut health, as they can act as modulators of the microbiota and stimulators of intestinal function (Lange et al., 2010). The phytochemical properties of these natural anti-inflammatory substances suggest that they can be used as potential therapeutic agents to attenuate unwanted immune responses (Fei et al., 2014). For example, essential oil extracted from Brazilian red pepper (EO) (Schinus terebinthifolius Raddi) has been shown to promote gut health (Gois et al., 2016) by acting as an antioxidant (Bendaoud et al., 2010), antimicrobial (de Lima et al., 2006), anti-inflammatory (Barbosa et al., 2007), and anti-ulcerogenic agent (Carlini et al., 2010, Carvalho et al., 2013). However, no studies have evaluated its effects on intestinal responses to inflammatory agents such as bacterial LPS.

The short-chain fatty acid sodium butyrate $(\mathrm{NaBu})$, derived from butyric acid, plays regulatory roles in intestinal function (Canani et al., 2011), including reduction of inflammatory responses through elimination of NF- $\mathrm{\kappa B}$ constitutive p50 dimer in HT-29 cells (Inan et al., 2000). Recently, in vitro studies confirmed that $\mathrm{NaBu}$ up-regulates the gene expression and activity of the brush border enzyme intestinal alkaline phosphatase (IAP) (Malo et al., 2006; Bol-Schoenmakers et al., 2010). IAP is an isoenzyme that hydrolyzes phosphate monoesters at alkaline pH (Sussman et al., 1989), and is able to detoxify bacterial components such as LPS (Koyama et al., 2002; Bates et al., 2007), flagellin, and CpG DNA (Chen et al., 2010) via dephosphorylation. Furthermore, it can prevent and reduce intestinal inflammation and bacterial translocation (Martínez-Moya et al., 2012).

Genetics and Molecular Research 15 (4): gmr15048875 
We hypothesized that $\mathrm{NaBu}$ and/or EO could up-regulate IAP, enhance gene expression of NF- $\kappa \mathrm{B}$ dimer RelA/p65, and hence attenuate LPS-induced inflammatory responses in ex vivo porcine jejunum tissues. The aim of this study was to evaluate the gene expression of IAP and RelA/p65 (NF- $\mathrm{kB}$ ) exposed to $\mathrm{NaBu}$ and/or EO, with or without LPS challenge, using an ex vivo model of intestinal explant.

\section{MATERIAL AND METHODS}

All animal handling procedures were approved by the Purdue Animal Care and Use Committee. Jejunal tissues $(30 \mathrm{~cm}$ in length) were collected from the stomach of five pigs weighing approximately $20 \mathrm{~kg}$. The jejunum was segmented into 10 parts $\left(2 \mathrm{~cm}^{2}\right)$ from each pig, and was randomly assigned to one of the treatments. Feed additives were supplied according to the following 10 treatments: T1 - control (without additives); T2 - $5 \mathrm{mM} \mathrm{NaBu}(\geq 98,5 \%$; Sigma Aldrich, St. Louis, MO, EUA); T3 - 2 ppm EO from Brazilian red pepper fruit (S. terebinthifolius Raddi; Agro Rosa Ltd Company, São Mateus, ES, Brazil); T4 - 5 mM NaBu + 2 ppm EO; T5 - 4 U/mL Calf IAP (Sigma Aldrich); T6 - $10 \mathrm{mg} / \mathrm{mL}$ Escherichia coli LPS; T7 - $10 \mathrm{mg} / \mathrm{mL}$ E. coli LPS $+5 \mathrm{mM} \mathrm{NaBu}$; T8 $-10 \mathrm{mg} / \mathrm{mL}$ E. coli $\mathrm{LPS}+2 \mathrm{ppm}$ EO; T9 $-10 \mathrm{mg} / \mathrm{mL}$ E. coli $\mathrm{LPS}+5$ $\mathrm{mM} \mathrm{NaBu}+2 \mathrm{ppm} \mathrm{EO}$; T10 - $10 \mathrm{mg} / \mathrm{mL}$ E. coli $\mathrm{LPS}+4 \mathrm{U} / \mathrm{mL}$ IAP. The major components found in EO fruit were described by Gois et al. (2016), and all experimental procedures were performed according to the protocol outlined by Bortoluzzi et al. (2016).

Gene expression analyses were performed via real-time PCR; levels of IAP(Lackeyram et al., 2010) and RelA/p65 (de los Santos et al., 2007) were evaluated with GAPDH as the reference gene (Smith et al., 2011). Relative mRNA expression was calculated according to the methods proposed by Livak and Schmittgen (2001). All experiments were replicated in two plates, and samples were analyzed in duplicates (four CT values for each treatment).

For statistical analysis, each jejunal explant collected from the piglets (10 explants/ piglet) was considered as one experimental unit $(\mathrm{N}=5$ replicates/treatment). The effect of treatments on gene expression levels was assessed using the Student $t$-test with unequal variance. Significance was determined to be $\mathrm{P} \leq 0.05$.

\section{RESULTS}

\section{LPS induced gene expression of IAP and RelA/p65 (NF-кB)}

The ability of LPS to induce inflammatory response is essential to evaluate the effectiveness of the ex vivo model used in this experiment, and to investigate the effect of the proposed treatments. Our model showed that the porcine jejunum tissue was responsive to LPS challenge, resulting in up-regulation $(\mathrm{P}<0.05)$ of IAP $(6.9 \pm 0.73$-fold higher than control) (Figure 1). Furthermore, RelA/p65 showed enhanced gene expression upon LPS treatment $(\mathrm{NF}-\kappa \mathrm{B})(4.35 \pm 0.3$-fold higher than control) (Figure 2).

\section{$\mathrm{NaBu}, \mathrm{EO}, \mathrm{NaBu}+\mathrm{EO}$, and exogenous IAP up-regulated IAP gene expression}

Regulation of IAP by various treatments in intestinal explants is shown in Figure 1. $\mathrm{NaBu}$ treatment resulted in an increase $(\mathrm{P}<0.05)$ in the relative mRNA expression of IAP by $8.21 \pm 1.15$-fold as compared with control treatment. In addition, EO (7.07 \pm 0.98 -fold higher

Genetics and Molecular Research 15 (4): gmr15048875 
than control) and combination treatment of $\mathrm{NaBu}+\mathrm{EO}(8.7 \pm 0.76$ fold-higher than control) were also able to up-regulate $(\mathrm{P}<0.05)$ IAP gene expression. Furthermore, exogenous IAP further increased IAP gene expression $(\mathrm{P}<0.05 ; 7.41 \pm 1.44$-fold $)$, suggesting that IAP in the intestinal lumen acts as stimulator agent to cellular IAP expression.

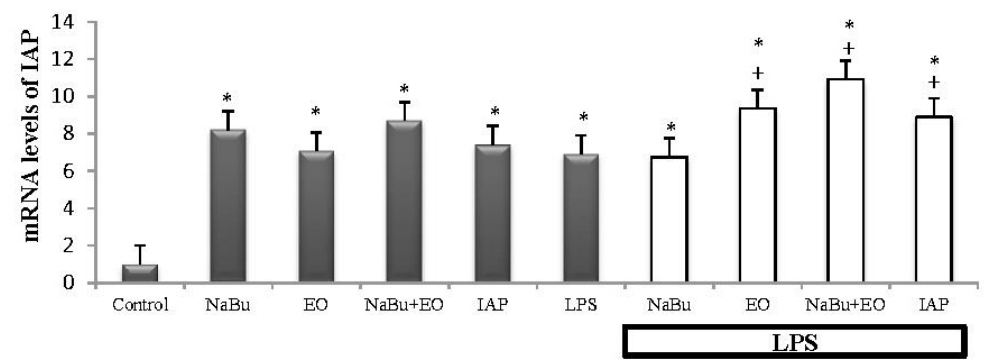

Figure 1. Gene expression of intestinal alkaline phosphatase (IAP) in porcine jejunum induced by different treatments as determined by qRT-PCR (expressed as fold higher than control based on $2^{-\Delta \Delta C t}$, using GAPDH as reference gene). ${ }^{*} \mathrm{P}<0.05$ control $v s$ treatments. ${ }^{+} \mathrm{P}<0.05$ LPS $v s$ additive + LPS.

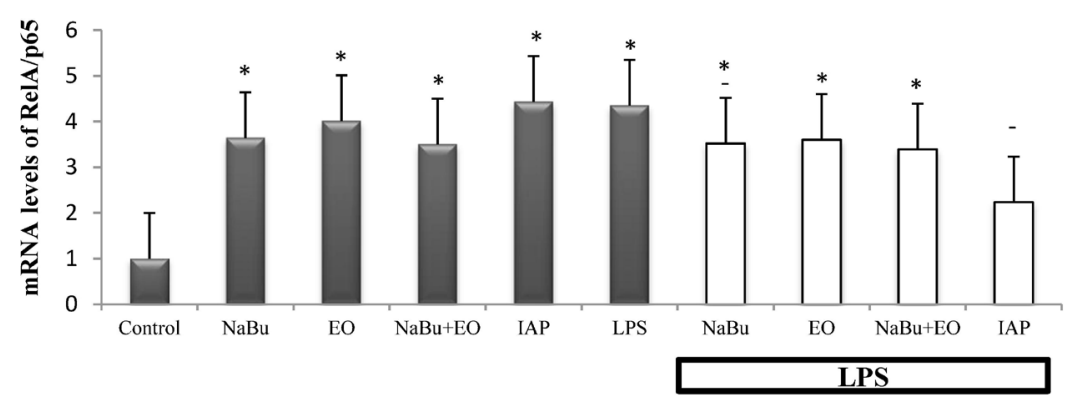

Figure 2. Gene expression of RelA/p65 $(\mathrm{NF}-\mathrm{\kappa B})$ in porcine jejunum induced by different treatments as determined by qRT-PCR (expressed as fold higher than control based on $2^{-\Delta \Delta C t}$, using GAPDH as reference gene). ${ }^{*} \mathrm{P}<0.05$ control $v s$ treatments. $-\mathrm{P}<0.05$ LPS $v s$ additive + LPS.

\section{Treatments complementarily up-modulated IAP gene expression in LPS presence}

The relative mRNA levels of IAP from porcine explants treated with LPS+EO, LPS $+\mathrm{NaBu}+\mathrm{EO}$, and LPS $+\mathrm{IAP}$ were significantly higher $(\mathrm{P}<0.05)$ as compared with that of LPS-only treatment $(36,58$, and $29 \%$, respectively). This suggests that these combination treatment have synergistic effects (Figure 1). However, there was no difference $(\mathrm{P}>0.05)$ in gene expression of IAP when tissues were exposed to LPS $+\mathrm{NaBu}$, as compared to that observed with LPS treatment.

\section{RelA/p65 (NF-кB) gene expression was up-regulated by the treatments}

The ex vivo findings in this study showed higher $(\mathrm{P}<0.05)$ relative mRNA levels of RelA/p65 (NF-kB) in porcine explants exposed to $\mathrm{NaBu}(3.64 \pm 0.52$-fold higher than control), EO (4.01 \pm 0.4 -fold higher than control), NaBu+EO (3.50 \pm 0.68 -fold higher than control), and exogenous IAP (4.43 \pm 0.5 -fold) as compared with that of the control (Figure 2$)$. 


\section{$\mathrm{NaBu}$ and exogenous IAP suppressed gene expression of RelA/p65 (NF-кB) in response to LPS challenge}

The anti-inflammatory effect of the treatments was investigated in porcine jejunum tissue during LPS challenge (Figure 2). When tissues were exposed to LPS+NaBu, LPS $+\mathrm{EO}$, and LPS $+\mathrm{NaBu}+\mathrm{EO}$, the expression of RelA/p65 (NF-kB) was up-regulated and was $3.52 \pm 0.46-, 3.6 \pm 0.68$-, and $3.39 \pm 0.97$-fold higher than that of the control,

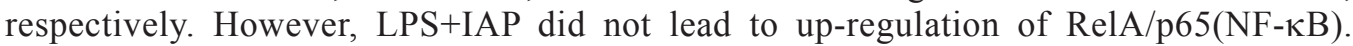
When compared to LPS treatment, explants exposed to LPS $+\mathrm{NaBu}$ and LPS+IAP showed suppressed LPS stimulation ( $\mathrm{P}<0.05)$, as demonstrated by reduced mRNA levels of RelA/ p65 (NF-кB). Lastly, only exogenous IAP was capable of down-regulating LPS-induced inflammatory responses, $(\mathrm{P}>0.05)$, as assessed by relative mRNA expression of RelA/ p65 (NF- $\mathrm{KB})$ as compared with that of the control.

\section{DISCUSSION}

The gastrointestinal tract is continuously exposed to various microorganisms. The Tolllike receptor 4 (TLR4) recognizes bacterial LPS as pathogen-associated molecular patterns (PAMPs) (Takeda and Akira, 2004), and stimulates the immune response via activation of

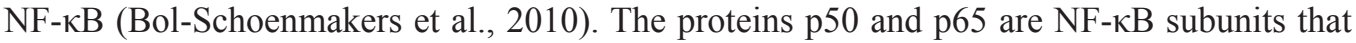
are highly expressed during signaling cascades (Baeuerle and Henkel, 1994; Goldberg et al., 2008). While there are several mechanisms by which inflammatory processes may occur, the common final response to NF- $\mathrm{KB}$ signaling is the release of cytokines, chemokines, and the recruitment of inflammatory cells (Berkes et al., 2003).

Recently, the role of IAP in detoxifying LPS and reducing the inflammatory response has been investigated (Koyama et al., 2002; Bates et al., 2007; Bol-Schoenmakers et al., 2010; Chen et al., 2011). It has been demonstrated that early weaning of piglets reduces the expression of IAP mRNA, and may predispose animals to enteric infections and diarrhea events, resulting in poor health and impaired growth (Lackeyram et al., 2010). In mice, the activity of alkaline phosphatase increases following colitis induction, which mimics IBD conditions in humans; exogenous IAP treatment reduced inflammatory markers and bacterial translocation (Martínez-Moya et al., 2012). However, there are no reports regarding the ability of exogenous IAP to regulate endogenous IAP expression. A few studies have suggested that herbal extracts and sodium butyrate may play a role in regulating IAP expression (Malo et al., 2006; Levkut et al., 2011). The present investigation demonstrated that $\mathrm{EO}, \mathrm{NaBu}$ and exogenous IAP all up-regulate intestinal levels of IAP, which can contribute to the maintenance of local intestinal immunity.

The modulatory effect of $\mathrm{NaBu}$ on the immune response was confirmed in the present study when jejunal explants exposed to $\mathrm{NaBu}$ showed enhanced gene expression of RelA/p65 $\mathrm{NF}-\kappa \mathrm{B}$. Activation of NF- $\kappa \mathrm{B}$ is dependent on its translocation to the nucleus. In a previous study, $\mathrm{NaBu}$ reduced $\mathrm{p} 50 \mathrm{NF}-\kappa \mathrm{B}$ in the nucleus without affecting p50 level in the cytoplasm (Inan et al., 2000). LPS, IL- $1 \beta$, and TNF- $\alpha$ can induce translocation of cytoplasmatic NF$\kappa \mathrm{B}$ into the nucleus, resulting in its activation. Bol-Schoenmakers et al. (2010) reported that following LPS challenge, cells exposed to the IAP up-regulator, $\mathrm{NaBu}$, showed suppressed NF$\kappa \mathrm{B}$. However, no further investigation was carried out on the NF- $\kappa B$ dimer produced in these LPS-induced cells. Other studies demonstrated that IL-1 $\beta$ treatment enhanced p65 expression,

Genetics and Molecular Research 15 (4): gmr15048875 
while suppression of p65 was observed in TNF- $\alpha$-treated cells exposed to $\mathrm{NaBu}$ (Inan et al.,

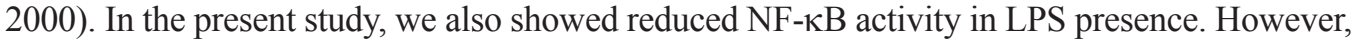
while NaBu blunted LPS and TNF- $\alpha$ induction, NF- $\kappa$ B activity was not reduced to basal levels, and its effect upon IL- $1 \beta$ seemed to be limited. Although there is a difference between p50- and p65-pathways, a possible explanation is that a part of the p50-p65 complex remains bonded after $\mathrm{NaBu}$ treatment, which can still activate gene transcription (Inan et al., 2000).

Pre-treatment of epithelial cell lines with $\mathrm{NaBu}$ before exposure to a PAMP that mimics bacterial LPS resulted in enhanced IL- 8 production, which may be mediated by NF$\kappa \mathrm{B}$ inactivation. $\mathrm{NaBu}$ silenced IL-8 induction following LPS challenge via overexpression of A20, a protein that down-regulates NF- $\mathrm{kB}$ signaling (Weng et al., 2007). In the present study, the reduction of $\mathrm{p} 65$ and increased IAP expression in response to LPS $+\mathrm{NaBu}$ treatment suggest that, at least in part, the overexpression of IAP may down-regulate NF$\kappa \mathrm{B}$ signaling. The mechanism of action was reported be through histone hyperacetylation (Malo et al., 2006). Other studies examining the effects of $\mathrm{NaBu}$ on intestinal inflammation with regard to other pathways were summarized by Canani et al. (2011). Taken together, NF- $\kappa B$ activation can be differentially modulated depending on various inductors (e.g., IL$1 \beta$, TNF- $\alpha$, LPS), and its anti-inflammatory effects could be mediated through up-regulation of IAP and/or A20, both of which down-regulate NF- $\kappa \mathrm{B}$ signaling. Indeed, the modulation of epithelial response induced by $\mathrm{NaBu}$ can attenuate inflammatory events according to severity of cell damage (Bol-Schoenmakers et al. 2010).

Herbal extracts (e.g., seaweed extract, borneol oil, ciwujia dried roots) have been reported to be enhancers (Leonard et al., 2012) and attenuators (Juhás et al., 2008; Bahar et al., 2012; Fei et al., 2014) of immune responses. Further, essential oils (e.g., oregano and thymol) (Jang et al., 2007; Levkut et al., 2011) and dietary spices (black pepper, piperine, red pepper, capsaicin, and ginger) (Prakash and Srinivasan, 2010) have been shown to modulate IAP activity. The nonpolar property of these spices can facilitate interaction with lipids and hydrophobic portions of proteins, which was suggested to increase the intestinal brush border membrane fluidity, digestive enzymes, protein transporters, and nutrient absorption (Prakash and Srinivasan, 2010). In our study, we found that EO was able to up-regulate jejunal IAP mRNA. Nevertheless, this regulation was not able to suppress LPS-induced inflammatory response. It is possible that greater dose of EO is needed to silence LPSinduced intestinal inflammation via IAP modulation.

To the best of our knowledge, this is the first study reporting the combined effect of $\mathrm{NaBu}$ and $\mathrm{EO}$ in enhancing intestinal immune response and IAP production. We initially hypothesized that this combination therapy could positively complement the anti-inflammatory effects of $\mathrm{NaBu}$. However, when tissue samples were exposed to LPS, production of RelA/p65 $(\mathrm{NF}-\kappa \mathrm{B})$ in response to $\mathrm{NaBu}+\mathrm{EO}$ was comparable to that of the control.

The ex vivo model used in this investigation has been well accepted as a valid method both to test injury induction from potential mitigating agents (Bahar et al., 2012; da Silva et al., 2014; Bortoluzzi et al., 2016). Indeed, we saw that intestinal explants could respond directly to exogenous inductors such as LPS, natural substances, and brush border enzyme. Under in vitro conditions, since diets between animals and humans differ, the nutrients consumed may also differentially modulate intestinal mucosa responses. Furthermore, diets alter the intestinal microbiota, which also can promote a variety of mucosal responses. To reduce this limitation, ex vivo studies can evaluate acute responses of intestinal explants from animal that received different diets. This allows for better understanding of the

Genetics and Molecular Research 15 (4): gmr15048875 
interactions between food, microbiota, natural toxins, preventive and therapeutic agents, and host responses. To summarize, knowledge from ex vivo, in vivo, and genetic studies could all contribute to maintenance of intestinal health.

In this study, we found evidence to suggest that dietary supplementation with exogenous IAP or natural agents is able to maintain the expression and activity of IAP in the intestinal mucosa, and enhances intestinal immunity responses against bacterial-induced inflammation. Reducing LPS toxicity is an emerging strategy to reduce intestinal inflammation. Exogenous IAP is a beneficial agent that acts to detoxify LPS, thus improving intestinal health.

\section{Conflicts of interest}

The authors declare no conflict of interest.

\section{ACKNOWLEGMENTS}

Antonio Diego Brandão Melo thanks the Science Without Borders Program (CNPq) from the Brazilian government for financing his internship at Purdue University. The authors also would like to thank the Purdue University and Pontifícia Universidade Católica do Paraná (PUCPR) for funding this study.

\section{REFERENCES}

Baeuerle PA and Henkel T (1994). Function and activation of NF- $\mathrm{B}$ in the immune system. Anпи. Rev. Immunol. 12: 141-179. http://dx.doi.org/10.1146/annurev.iy.12.040194.001041

Bahar B, O'Doherty JV, Hayes M and Sweeney T (2012). Extracts of brown seaweeds can attenuate the bacterial lipopolysaccharide-induced pro-inflammatory response in the porcine colon ex vivo. J. Anim. Sci. 90 (Suppl 4): 4648. http://dx.doi.org/10.2527/jas.53944

Barbosa LCA, Demuner AJ and Clemente AD (2007). Seasonal variation in the composition of volatile oils from Schinus terebinthifolius Raddi. Quim. Nova 30: 1959-1965. http://dx.doi.org/10.1590/S0100-40422007000800030

Bates JM, Akerlund J, Mittge E and Guillemin K (2007). Intestinal alkaline phosphatase detoxifies lipopolysaccharide and prevents inflammation in zebrafish in response to the gut microbiota. Cell Host Microbe 2: 371-382. http://dx.doi. org/10.1016/j.chom.2007.10.010

Basso K, Gomes F and Bracarense AP (2013). Deoxynivanelol and fumonisin, alone or in combination, induce changes on intestinal junction complexes and in E-cadherin expression. Toxins 5: 2341-2352. http://dx.doi.org/10.3390/ toxins5122341

Bendaoud H, Romdhane M, Souchard JP, Cazaux S, et al. (2010). Chemical composition and anticancer and antioxidant activities of Schinus molle L. and Schinus terebinthifolius Raddi berries essential oils. J. Food Sci. 75: C466-C472. http://dx.doi.org/10.1111/j.1750-3841.2010.01711.x

Berkes J, Viswanathan VK, Savkovic SD and Hecht G (2003). Intestinal epithelial responses to enteric pathogens: effects on the tight junction barrier, ion transport, and inflammation. Gut 52: 439-451. http://dx.doi.org/10.1136/gut.52.3.439

Bol-Schoenmakers M, Fiechter D, Raaben W, Hassing I, et al. (2010). Intestinal alkaline phosphatase contributes to the reduction of severe intestinal epithelial damage. Eur. J. Pharmacol. 633: 71-77. http://dx.doi.org/10.1016/j. ejphar.2010.01.023

Bortoluzzi C, Menten JFM, Silveira H, Melo ADB, et al. (2016). Hops $\beta$-acids (Humulus lupulus) decrease intestinal gene expression of proinflammatory cytokines in an ex vivo model. J. Appl. Poult. Res. 25: 1-6.

Canani RB, Costanzo MD, Leone L, Pedata M, et al. (2011). Potential beneficial effects of butyrate in intestinal and extraintestinal diseases. World J. Gastroenterol. 17: 1519-1528. http://dx.doi.org/10.3748/wjg.v17.i12.1519

Carlini EA, Duarte-Almeida JM, Rodrigues E and Tabach R (2010). Antiulcer effect of the pepper trees Schinus terebinthifolius Raddi (aroeira-da-praia) and Myracrodruon urundeuva Allemão, Anacardiaceae (aroeira-do-sertão). Rev. Bras. Farmacogn. 20: 140-146. http://dx.doi.org/10.1590/S0102-695X2010000200001

Genetics and Molecular Research 15 (4): gmr15048875 
Carvalho MG, Melo AGN, Aragão CFS, Raffin FN, et al. (2013). Schinus terebinthifolius Raddi: chemical composition, biological properties and toxicity. Rev. Bras. Plant. Med. 15: 158-169. http://dx.doi.org/10.1590/S1516$\underline{05722013000100022}$

Chen KT, Malo MS, Moss AK, Zeller S, et al. (2010). Identification of specific targets for the gut mucosal defense factor intestinal alkaline phosphatase. Am. J. Physiol. Gastrointest. Liver Physiol. 299: G467-G475. http://dx.doi. org/10.1152/ajpgi.00364.2009

Chen KT, Malo MS, Beasley-Topliffe LK, Poelstra K, et al. (2011). A role for intestine alkaline phosphatase in maintenance of local gut immunity. Dig. Dis. Sci. 56: 1020-1027.

da Silva EO, Gerez JR, Drape TC and Bracarense APFRL (2014). Phytic acid decreases deoxynivalenol and fumonisin B1induced changes on swine jejunal explants. Toxicol. Rep. 1: 284-292. http://dx.doi.org/10.1016/j.toxrep.2014.05.001

de Lima MR, de Souza Luna J, dos Santos AF, de Andrade MC, et al. (2006). Anti-bacterial activity of some Brazilian medicinal plants. J. Ethnopharmacol. 105: 137-147. http://dx.doi.org/10.1016/j.jep.2005.10.026

de los Santos T, Diaz-San Segundo F and Grubman MJ (2007). Degradation of nuclear factor kappa B during foot-andmouth disease virus infection. J. Virol. 81: 12803-12815. http://dx.doi.org/10.1128/JVI.01467-07

Fei XJ, Zhu LL, Xia LM, Peng WB, et al. (2014). Acanthopanax senticosus attenuates inflammation in lipopolysaccharideinduced acute lung injury by inhibiting the NF-kB pathway. Genet. Mol. Res. 13: 10537-10544. http://dx.doi. org/10.4238/2014.December.12.16

Gois FD, Cairo PLG, Cantarelli VS, Costa LCB, et al. (2016). Effect of Brazilian red pepper (Schinus terebinthifolius Raddi) essential oil on performance, diarrhea and gut health of weanling pigs. Livest. Sci. 183: 24-27. http://dx.doi. org/10.1016/j.livsci.2015.11.009

Goldberg RF, Austen WG, Jr., Zhang X, Munene G, et al. (2008). Intestinal alkaline phosphatase is a gut mucosal defense factor maintained by enteral nutrition. Proc. Natl. Acad. Sci. USA 105: 3551-3556. http://dx.doi.org/10.1073/ pnas. 0712140105

Inan MS, Rasoulpour RJ, Yin L, Hubbard AK, et al. (2000). The luminal short-chain fatty acid butyrate modulates NFkappaB activity in a human colonic epithelial cell line. Gastroenterology 118: 724-734. http://dx.doi.org/10.1016/ $\underline{\text { S0016-5085(00)70142-9 }}$

Islam $\mathrm{Z}$ and Pestka JJ (2006). LPS priming potentiates and prolongs proinflammatory cytokine response to the trichothecene deoxynivalenol in the mouse. Toxicol. Appl. Pharmacol. 211: 53-63. http://dx.doi.org/10.1016/j.taap.2005.04.031

Jang IS, Ko YH, Kang SY and Lee CY (2007). Effect of a commercial essential oil on growth performance, digestive enzyme activity and intestinal microflora population in broiler chickens. Anim. Feed Sci. Technol. 134: 304-315. http://dx.doi.org/10.1016/j.anifeedsci.2006.06.009

Juhás S, Cikos S, Czikková S, Veselá J, et al. (2008). Effects of borneol and thymoquinone on TNBS-induced colitis in mice. Folia Biol. (Praha) 54: 1-7.

Koyama I, Matsunaga T, Harada T, Hokari S, et al. (2002). Alkaline phosphatases reduce toxicity of lipopolysaccharides in vivo and in vitro through dephosphorylation. Clin. Biochem. 35: 455-461. http://dx.doi.org/10.1016/S00099120(02)00330-2

Lackeyram D, Yang C, Archbold T, Swanson KC, et al. (2010). Early weaning reduces small intestinal alkaline phosphatase expression in pigs. J. Nutr. 140: 461-468. http://dx.doi.org/10.3945/jn.109.117267

Lange CFM, Pluske J, Gong J and Nyachoti CM (2010). Strategic use of feed ingredients and feed additives to stimulate gut health and development in young pigs. Livest. Sci. 134: 124-134. http://dx.doi.org/10.1016/j.livsci.2010.06.117

Leonard SG, Sweeney T, Bahar B and O’Doherty JV (2012). Effect of maternal seaweed extract supplementation on suckling piglet growth, humoral immunity, selected microflora, and immune response after an ex vivo lipopolysaccharide challenge. J. Anim. Sci. 90: 505-514. http://dx.doi.org/10.2527/jas.2010-3243

Levkut M, Marcin A, Vieira R, Lenhardt L, et al. (2011). Influence of oregano extract on the intestine, some plasma parameters and growth performance in chickens. Acta Vet. 61: 215-225. http://dx.doi.org/10.2298/AVB1103215L

Livak KJ and Schmittgen TD (2001). Analysis of relative gene expression data using real-time quantitative PCR and the 2- $\Delta \Delta \mathrm{Ct}$ method. Methods 25: 402-408. http://dx.doi.org/10.1006/meth.2001.1262

Malo MS, Biswas S, Abedrapo MA, Yeh L, et al. (2006). The pro-inflammatory cytokines, IL-1beta and TNF-alpha, inhibit intestinal alkaline phosphatase gene expression. DNA Cell Biol. 25: 684-695. http://dx.doi.org/10.1089/ dna.2006.25.684

Malo MS, Moaven O, Muhammad N, Biswas B, et al. (2014). Intestinal alkaline phosphatase promotes gut bacterial growth by reducing the concentration of luminal nucleotide triphosphates. Am. J. Physiol. Gastrointest. Liver Physiol. 306: G826-G838. http://dx.doi.org/10.1152/ajpgi.00357.2013

Martínez-Moya P, Ortega-González M, González R, Anzola A, et al. (2012). Exogenous alkaline phosphatase treatment complements endogenous enzyme protection in colonic inflammation and reduces bacterial translocation in rats. Pharmacol. Res. 66: 144-153. http://dx.doi.org/10.1016/j.phrs.2012.04.006

Genetics and Molecular Research 15 (4): gmr15048875 
Prakash UN and Srinivasan K (2010). Beneficial influence of dietary spices on the ultrastructure and fluidity of the intestinal brush border in rats. Br. J. Nutr. 104: 31-39. http://dx.doi.org/10.1017/S0007114510000334

Roura E, Koopmans SJ, Lallès JP, Le Huerou-Luron I, et al. (2016). Critical review evaluating the pig as a model for human nutritional physiology. Nutr. Res. Rev. 29: 60-90. http://dx.doi.org/10.1017/S0954422416000020

Smith AG, O'Doherty JV, Reilly P, Ryan MT, et al. (2011). The effects of laminarin derived from Laminaria digitata on measurements of gut health: selected bacterial populations, intestinal fermentation, mucin gene expression and cytokine gene expression in the pig. Br. J. Nutr. 105: 669-677. http://dx.doi.org/10.1017/S0007114510004277

Sussman NL, Eliakim R, Rubin D, Perlmutter DH, et al. (1989). Intestinal alkaline phosphatase is secreted bidirectionally from villous enterocytes. Am. J. Physiol. 257: G14-G23.

Takeda K and Akira S (2004). TLR signaling pathways. Semin. Immunol. 16: 3-9. http://dx.doi.org/10.1016/j. $\underline{\operatorname{smim} .2003 .10 .003}$

Weng M, Walker WA and Sanderson IR (2007). Butyrate regulates the expression of pathogen-triggered IL-8 in intestinal epithelia. Pediatr. Res. 62: 542-546. http://dx.doi.org/10.1203/PDR.0b013e318155a422

Genetics and Molecular Research 15 (4): gmr15048875 